\title{
A Sociological Study of Graffiti in Seville, Spain
}

\author{
Amanda Marie Bunting ${ }^{\mathrm{a}}$
}

In Seville, Spain graffiti is so prevalent that it creates the background of the city. The artists are rarely seen due to the heavy fines imposed by local government. The illegality of graffiti leaves the artists to live within a deviant subculture of their own. This study's main analysis is data from nine qualitative interviews with artists from various cities in Spain using support from graffiti found in Seville. Commonalties of this subculture as well as differences from American artists were found and discussed.

Keywords: Graffiti, Delinquency, Subculture, Becker

\section{Introduction}

Graffiti has been referred to as, "a frequently overlooked form of communication" (Gach, 1973). In sociological research, studies on graffiti are hard to come by. Little to no research has been done on graffiti cross culturally, leaving these differences overlooked. The lack of previous study should not lead to the assumption that graffiti is of little importance. Instead, "the graffito represents part of 'a twilight zone of communication,' an outlet for often deeply felt, but rarely articulated, sentiments and attitudes" (Ley \& Cybriwsky, 1974: 492). In North America, findings of graffiti as gang territory markers have been validated by studies such as Ley \& Cybriwsky in 1974. Their study in Philadelphia states "wall graffiti offers an accurate indicator of turf ownership" (Ley \& Cybriwsky, 1974: 496). The graffiti consists of "signatures, a nickname, often followed by the gang name" (Ley \& Cybriwsky, 1974:496).

This research suggests that rather than gang markings, Spanish graffiti is an expression of art. This is exemplified through the photos and interviews completed. Unlike American gangs, Spanish artists form crews which share a graffito subculture that focuses on art rather than delinquency.

Becker (1963: 81) states that, "people who engage in activities regarded as deviant typically have the problem that their view of what they do is not shared by other members of society." Graffitists view their work as art, and others view it as delinquency. The graffitists, according to Becker's theory, are justifying the fact that their spray-painting is illegal by calling it art; "justifications for deviance that are seen as valid by the delinquent but not by the legal system or society at large" (Becker: 1963: 28). Following Becker, this technique of neutralization for graffitists is also manifested in the fact that graffiti is a 'victimless' crime. The artists can claim "that the injury... is not really an injury" (Becker: 1963: 29).

\section{Acknowledgements}

Hood College and the Second Century Grant for funding. Dr. Kerry Strand for advising this project and contributing to this paper with her expertise and thoughts.
To understand graffiti, we must first recognize that graffiti is more than writing on the wall. Graffiti artists form a deviant subculture which maintains its own lifestyle and patterns of behavior.

\section{Experimental Procedures}

The research design is composed of two parts. The first is based on photos taken in Seville, Spain; chosen because it is the artistic capital of the south and home to massive amounts of graffiti. The second part is based on interviews with graffitists. The data consisted of approximately 150 pieces of graffiti that were taken in Seville in January of 2009. Only tags and pieces on walls were photographed, excluding latranilia or any other surfaces. The photos are from the center of Seville, in the side streets by the Cathedral, the walls by the bridges of the Gualdquivir River, and the skate park near the Plaza de Armas bus station over a span of fifteen days. These specific areas were chosen because they are the most well known and contained the most graffiti. Instead of just one piece on one wall, the bridges and skate park are fully covered from top to bottom, side to side, with different pieces of graffiti. The Cathedral area was chosen because it was the most rich with tags rather than pieces. Its narrow streets make elaborate wall pieces difficult, if not impossible, to paint. At these various sites a total of 400 pictures were gathered. Using photo software the photos were combined to recreate the full wall pieces, which left 150 photos.

Due to time constraints these were the only areas photographed. A future evaluation of these photos will allow common themes and artists to be compared. Therefore any similarities of the photos, except to note that the same artists painted in several areas, are not interpreted in this paper.

The other half of the data consisted of nine qualitative interviews with graffiti artists in Spain. These artists were found by posting a photo on tuenti.com, a private Spanish social network, where artists tagged their fellow graffiti artists to participate in interviews via Windows Messenger. Tagging refers to the fact that anytime the photo received comments on the picture, everyone tagged in the photo will receive notification of the information quickly and easily. From this snowball sample, the interviews were conducted. The artists who replied ranged from ages fifteen to twenty-four with the average age being eighteen. The amount of time since they began painting ranged from one year to nine years. The average 
amount of experience was three and a half years. The artists were from multiple cities in Spain. Two were from the city of Seville, two from Madrid, one from Jerez which is located in the south close to Seville, and four from cities surrounding Madrid and north of Seville to include; Segovia, Valladolid, Caceres, and Castellon.

All artists were asked the same semi-structured questions. They were asked their age, how long they had been painting, which city or cities they painted in, if they were part of a crew, if they painted on legal or illegal surfaces, and if they were involved in rap culture. These questions were asked in order to reveal similarities between the artists. To gain a more in-depth, personal understanding the artists were also asked several more questions that elaborated on the previous. When asked if they were part of a crew, the question was followed up by asking how they were inducted into this crew or to explain how they started the crew. Legal and illegal painting habits were explored through questions about adrenaline rushes, if the artists thought graffiti should be legal, and allowing the artists to explain their legal and illegal habits. The artists were asked how many times a week or every fifteen days they painted and if they sketched daily. It was asked if they painted alone and if they smoke or drank while painting. If they had any police encounters, the repercussions were explored and many artists shared stories about members of their crews who had negative experiences with the police. The artists' feelings on graffiti as a form of art or an act of delinquency was discussed and conversation from that point surrounded topics the graffitists brought up. These questions aimed to find similarities among the nine artists. They were not aware of the similarities found. If a pattern was found among a few interviews, old interviewees were contacted again in order to clarify or ask more questions. The interviews lasted anywhere from thirty minutes to an hour and a half which in messaging form ranged from six to twelve pages of text with the average number of pages being eight.

All interviews were conducted in Spanish and used informal language and slang. In order to gain a rapport with the artists the interviewer used similar colloquialisms and abbreviations that were picked up from various conversations. The language was a very interesting and complex situation. There were essentially three steps of translation that occurred. All the interviews took place in a colloquial Spanish that is used among this age group and on the internet. Just as in English slang one can type "U trynna go?" meaning "Are you trying to go?" the same can be done in Spanish. First, the interviews had to translate the Spanish slang into proper Spanish, and then translated into English. The quotes in this paper are not the originals; rather they are translated as clearly as possible in order to retain meaning. In addition, the graffitists in this article are referred to by the tag they use while painting. Artists were never asked for their real names for ethical reasons. Their tags are public knowledge since they have all been put on public walls.

The limitations to the data collection occurred in the qualitative interviews. The snowball sample of artists produced only a small population to choose from. Some artists, who originally wanted to participate, lost interest after time. Also, due to the expansive geographic market of the tuenti.com social network, artists from all over the country participated in the interview, while the photographic evidence was solely from Seville. While the geographic outreach was exciting due to the similarities found across the entire country it leaves the photographic evidence unable to support the subculture. In order to more properly control the issue of geography, the tuenti.com photo could be limited to artists from Seville which would have created the need for more time in order to gather interviewees. Alternatively, more photographic evidence could be gathered from other cities including the ones from which the artists interviewed painted. This would consume substantially more resources, and therefore more interviews from Seville only artists would be the most beneficial way to further support the study.

\section{Results}

\section{Tagging}

Spanish graffitists begin with tags, which are stylized signatures, logos, or nicknames drawn by the artist using one color of spray paint or sometimes marker, to indicate where in a city they frequent. These tags are used as identifiers and signatures on 'pieces.' The term 'piece' is derived from the word 'masterpiece'. Pieces are more elaborate than tags in that they use multiple colors, can expand the size of an entire wall, and can be completed by more than one artist.

In Seville, Spain tags were found from the same artists in all three places photographed. Their tags ranged from the small streets by the Cathedral, to walls along the river, which was on the walk to the skate park. The purpose of the plethora of tags around the city of Seville is so that the graffitists can spread their name, much like artists do, to receive recognition. They are not claiming territory as was found in Ley \& Cybriwsky study of gang graffiti in Philadelphia.

Artist Ska77 spoke of tags in his interview, "I think that a tag is art but it isn't worth it to just put your name on a wall. You should do it with your own style....you should feel what you are doing and do it to decorate the city, or represent your crew or yourself. But you have to find the look between a tag and the city to merge into each other."

Furthermore, the interviewees placed emphasis on tags being the beginning creation of their graffiti. Frequency of tags allows artists to become well known and helps to build their reputation.

\section{Commonalties of a deviant subculture}

According to Becker (1963) any group that shares a common form of life which entails common habits, beliefs, and rituals is considered a subculture. From the nine interviews, the unknown commonalities within this deviant subculture of graffiti artists were discovered. The graffitists in Spain create a deviant subculture through such commonalities as involvement in crews, participation in rap culture, illegal and legal painting habits, frequency of painting, sketching routine habits, desire of adrenaline, and their shared belief of graffiti as an art. Just as any subculture, graffitists have a clearly distinct lifestyle where their habits, beliefs, and rituals consume their day-to-day actions to the point where these are not mere common chances, but rather an entire form of life as a graffitist.

\section{Crews and Rap Culture}

A graffiti crew is a group usually ranging anywhere from two to forty members who gather to work on pieces together. In this case, the nine interviewed artists were all part of a crew; however none of them were a part of the same crew allowing for nine crews to be represented. 
As the artists conversed about their crews, a distinct similarity of the involvement of rap and hip-hop culture evolved. "Ecka" was one of the graffitists who was also a rapper, "I consider myself a rapper and I love rap even though I listen to more things.... I don't see it bad that someone who does graffiti isn't a rapper...in this world there's everything." Agreeing in his position was "Ska77" who stated,

"I believe that it's [rap] something that you can add to the graffiti and that it's in certain fashion in this society it's something that relates a lot to its [graffiti] beginnings... but I don't think you should be a bboy or a bgirl and that you have to like hip-hop in order to have the ability to paint...I don't see it as essential in fact I know a great graffitist that only listens to metal and he makes wonders."

Despite the consensus that rap was not an essential component to graffiti, the artists interviewed all enjoyed rap and hip-hop music, and some were even rappers themselves.

\section{Illegal and Legal Spraying}

The graffitists were asked about their legal and illegal painting habits. Legal graffiti includes legal yards, their own houses and property, and commissioned work. Illegal graffiti would include any public or private surface where graffiti is unwanted or considered illegal by the local laws. All artists partake in both, but even those who paint most of the time legally prefer illegal and find illegal to be 'real' graffiti. Evidence of this as represented in this conversation with "Goe":

"Interviewer: So you do you paint legal or illegal?

Goe: well both. It has it's part legal in that they order me to make things and they pay me for them or also at my house there are some white walls and I paint around here once in awhile and the other part of illegal also, like trains, the street, the store front gates...

Interviewer: and which do you like more?

Goe: ...I like both forms. The illegal is of risk and tension of painting fast without them seeing you. And later you pass by and you see....and the people see it.

Many artists shared this opinion, such as "Onda" in his remark, "I like illegal more, because it has more emotion, its more emotional."

As far as illegal graffiti being "real' graffiti, "Ska77" described this concept. "Later I thought that graffiti actually should be illegal in order to be graffiti...the objective already is to break the monotony of a city of grey....and to put a piece where you think is the best place..." The history of modern graffiti with its roots in New York and Philadelphia may have created the stereotype that in order for something to be truly deemed graffiti, it should be illegal. However, part of the reason that the artists interviewed preferred illegal is somewhat due to adrenaline.

Any situation where artists may be caught by the police, or when artists need to run from the police, as many of the artists interviewed had, will provoke a certain physical response and corresponding emotions. This adrenaline rush helps to explain why artists enjoy painting illegally. "Ecka" says of his painting habits, "a lot of the time I like to go for the illegal because it's morbid that they might catch you, always addictive." All the artists shared this feeling, including "Eroz" who stated, "Well with the fear, the adrenaline of the moment, that in that moment before they catch you and things are messed up or if they don't catch you, you'll be a little talked about among those who are starting to paint and that they aren't bold enough [to paint illegally], it's the best." While some deviant subcultures use drugs to achieve this high feeling and addiction, graffiti artists naturally achieve it by painting illegally.

The artists interviewed were also asked about how often they partook in legal or illegal painting. The graffitists paint around three times every month, if not more. "Fakir" shared this habit, although he had one month where other circumstances kept him from painting:

"Fakir: it depends. There was one month that I didn't paint but before one time, one time every week at the least.

Interviewer: Why didn't you paint during this month? Busy with other things?

Fakir: Yes, I have been distracted with other things and with the crisis I didn't have a lot of money for sprays.

It is interesting that the world economic crisis is affecting graffitists painting habits. The other artists have similar habits of painting every week. Some artists who were also students stated that they painted three times per month due to exams and school work.

Even though artists cannot paint regularly, they still draw sketches daily. "Ska77" explained it as, "...a form of life. I always have letters going around the head and every time I go out to the streets...I see a place and I imagine that a piece will be there." When asked if he sketched daily he responded, "Yes but not always sketches of letters, but overall variety of drawings. When one gets involved with graffiti truthfully, in the head there is nothing more than the appearance of sketches and sketches and different models. It's like a sickness." With the twenty first century and the new level of technology; artists are taking their sketches to an advanced level, using Photoshop and other programs to make digital sketches.

\section{Art versus Delinquency}

With all of these similar habits and feelings, the most emotional intense similarity is that of the perception of graffiti as an art or delinquency. According to Becker's theory, graffitists' problem is that their view on graffiti is not the view that society holds for graffitists. This, as expected, was found to be the case among those interviewed. When "Eroz" was asked if he felt graffiti was an art or delinquency he responded, "Art because it's a form of expressing feelings that you can't explain to people face-to-face." When addressing delinquency "Ecka" said, "Delinquency I see more as robbery. It's [graffiti] a form of expression." Despite the graffitists' strong feelings that graffiti is an art, it remains illegal where they live.

\section{Discussion}

In accordance with Becker's theory in defining deviance and subcultures, the data gathered leads to the impression that graffitists in Spain make up a deviant subculture. The artists are from different cities and different crews, yet they share common practices and beliefs. The most prominent are the belief that graffiti is an art form, the involvement of rap and hip-hop music, their involvement in crews, their frequency of painting to include both legal and illegal places, and the adrenaline addiction that comes as a direct result of illegal painting.

The fact that the interviews composed of artists across Spain leads to the thought that location does not matter for this subculture. Clearly, more interviews would need to be 
completed to conclude that this is true. The interviews are not representative of all graffitists in Spain, but there is a definite pattern despite the geography. It would be interesting to continue this study in other European countries and to look for cross-country similarities within this deviant subculture.

The photographic graffiti evidence in Seville, illustrates that artists are not using graffiti to mark territory like in the United States. The artists long for recognition of their artistic masterpieces and use their tags to help achieve this sense of fame. This is not representative of all of Spain since regionally graffiti differs in message. More research needs to be done to analyze the actual presence of gangs in Spain.

There is no denying graffiti is an art form despite its ties with delinquency. The graffiti blends into the city, and following the motivation of the graffitists, creates a public art for all to see. The rush that artists receive when painting illegally, coupled with the consensus that true graffiti is painted illegally raises a question. If this art form was legalized, would it not take away the very essence that the graffitists claim to love the most? As artists "Ska77" put it, "the graffiti represents this...the soul of the urban city."

\section{References}

Becker, Howard S. 1963. Outsiders. New York, NY: Free Press

Cooper, Martha and Chaflant, Henry. 1984. Subway Art. New York, NY: Holt, Rinehart \& Winston.

Gach, Vicki. 1973. "Graffiti.” College English 35:285-287.

Gadsby, Jane M. 1995. "Looking at the Writing on the Wall: A Critical Review and Taxonomy of Graffiti Texts." Art Crimes. Retrieved March 12, 2009

(http://www.graffiti.org/faq/critical.review.html)

Ganz, Nicholas. 2006. Graffiti World: Street Art from Five Continents. New York, NY: Harry N. Abrams Inc

Gonos, George, Virginia Mulkern, and Nicholas Poushinsky. 1976. "Anonymous Expression: A Structural View of Graffiti." The Journal of American Folklore 89:40-48.

Graffiti.org

Lachmann, Richard. 1988. "Graffiti as Career and Ideology." The American Journal of Sociology 94:229-250.

Ley, David and Roman Cybriwsky. 1974. "Urban Graffiti as Territorial Markers." Annals of the Association of American Geographers 64:491-505.

Nilsen, Don L. F. 1980. "The Grammar of Graffiti." American Speech 55:234-239.

Peteet, Julie. 1996. "The Writing on the Walls: The Graffiti of the Intifada." Cultural Anthropology 11:139-159.

Sheon, Aaron. 1976. "The Discovery of Graffiti." Art Journal $36: 16-22$ 